\title{
Improving the Quality of Higher Education
}

\section{to the Indonesian Golden Awakening Generation}

\author{
(A General Review of the Education Sector in Indonesia)
}

\author{
${ }^{1}$ Fatimah Abdillah, ${ }^{2}$ Rita Yuni Mulyanti \\ Management Dept. Pandu Madania College of Economics \\ Cibungbulang KM 15, Bogor 16630, Indonesia \\ E-mail : Abdillah.fatimah@yahoo.com
}

\begin{abstract}
Indonesia has experienced a period of success in education with a Gross Participation Rate (GER) in higher education is expected to increase approximately $0.75 \%$ every year from 2008. Nowadays Indonesia has been facing an extra demographic phase (2025-2035) where the number of productive age is more than non-productive age. Some special attention has been given by the government particularly the ministry of education and culture to prepare the demographic dividend through guidance to develop a civil society. The nation's best quality is mainly generated from the appropriate education quality and good character. The education that builds faith and piety as well as science and technology will eventually shape the nation strong character and globally competitive. The guiding and training to build the character of civil society needs competent educators and good management of the leaders in each college by requiring quality culture. The educator should be competent in civil personality, social, professionals in the field of knowledge, combined with the activity of Tri Dharma Perguruan Tinggi, and the competence of educating and teaching (pedagogic). In addition, the educator should have a commitment to the institution or college. The leadership which is committed to a culture of quality and entrepreneurship character should be attached to every University leader.
\end{abstract}

Keywords : Demographic Bonus Phase, Madani Character, Education Quality.

\section{INTRODUCTION}

In 2004 to 2008, Indonesia has managed to increase better higher education participation rates. Based on the data from the 2010-2014 strategic plan of the ministry of education and culture of Indonesia, data showed that the higher education GER increasing rate (GER) from $14.62 \%$ in 2004 to $17.75 \%$ in 2008 , and it is estimated to be $18.50 \%$ in 2009 . In 2008 a certificate of competence of higher education reached to 193206 copies. Development of the percentage of qualified lecturers in public universities S2/S3 from 2004 to 2008 fluctuated with the estimated performance in 2009 reached $70.43 \%$. Teacher certification was conducted in 2008 by $7.4 \%$ on target. Statistical increases in the number of patents and international publications indicate that the climate on better-quality studies is getting better (Table I).
However, nowadays Indonesia should give special attention to obtain demographic bonus phase (2025-2035) by increasing productivity and economic growth. Demographic dividend is the stage where the condition of the population age structure makes the dependency ratio is at a low level. Dependency ratio shows a comparison between the productive and non productive age, which means how many people describe the non-productive age whose life is supported by the productive age group. 2025-2035 period, Indonesia has a dependency ratio ranged from 0.4 to 0.5 , which means 100 people age support the unproductive $40-50$ age people. The rate of dependency ratio is smaller compared to the year 2010 and 1971 come to 0.51 and 0.86. There are four prerequisites must be met to obtain a demographic bonus. First, young people should have a productive job and can save money. Second, household savings can be invested to create productive jobs. Third, investments created to enhance human capital in taking advantage of the momentum of opportunity will come. Fourth, create an environment in which women enter the labor market (Srihadi. 2012)

TABLE I. INDONESIA HIGHER EDUCATION ACHIEVEMENTS YEAR $2004-2008$

\begin{tabular}{|c|c|c|c|c|c|c|}
\hline Program & Job Indikators & 2004 & 2005 & 2006 & 2007 & 2008 \\
\hline \multirow[t]{15}{*}{$\begin{array}{c}\text { Higher } \\
\text { Education }\end{array}$} & $\begin{array}{l}\text { GER of Higher Education } \\
(\%)\end{array}$ & 14,62 & 15 & 16,7 & 17,25 & 17,75 \\
\hline & $\begin{array}{l}\text { GER Vocational Higher } \\
\text { education }(\%)\end{array}$ & 1,47 & 3,31 & 4,96 & 3,86 & 3,8 \\
\hline & $\begin{array}{l}\text { Sertificates published } \\
\text { (sheet)- Higher Education } \\
\text { (vocational and proffesion) }\end{array}$ & - & - & - & 144,292 & 193,206 \\
\hline & $\begin{array}{l}\text { Qualified Lectures S2-S3 } \\
(\%)\end{array}$ & 50 & 50 & 54,02 & 50,64 & 52,05 \\
\hline & $\begin{array}{l}\text { Education Certified } \\
\text { Lectures }(\%) \\
\end{array}$ & - & - & - & - & $\overline{7,4}$ \\
\hline & 500 World Top Universities & ank) & & & & \\
\hline & $<=300$ & 0 & 0 & 3 & 0 & 1 \\
\hline & $301<=x<=400$ & 0 & 1 & 0 & 3 & 2 \\
\hline & $401<=x<=500$ & 0 & 2 & 1 & 3 & 0 \\
\hline & $>=500$ & 0 & 0 & 0 & 0 & 3 \\
\hline & OECD Accredited Colleges & & 1(UT) & 1(UT) & 1(UT) & 1(UT) \\
\hline & Patent gained & 5 & 4 & 11 & 32 & 43 \\
\hline & $\begin{array}{ll}\text { Internasional } & \text { publication } \\
\text { Increase }(\%) & \end{array}$ & 5 & 7,5 & 25 & 43 & 43 \\
\hline & Equality Gender ratio & 90,1 & 90,4 & 99,8 & 99,4 & 102,3 \\
\hline & $\begin{array}{l}\text { Gold medal of Internasional } \\
\text { Olympiad }\end{array}$ & 0 & 0 & 27 & 0 & 29 \\
\hline
\end{tabular}




\section{LITERATURE REVIEW: ISSUES ON THE SERVICE SUPPLY OF THE HIGHER EDUCATION}

Indonesia has opened up opportunities for every child to acquire education to the higher education regardless of male or female. However, apart from many who have achieved success and opportunity in the demographic bonus, Indonesia has been facing a lot of inequality in education that must be resolved.

A. Not all of Indonesia's population of reproductive age had an opportunity to study in college

In the 2025-2035 period, Indonesia will be met by the productive age. Thus improving the quality of human resources through access to higher education for the 19-23 age range will be very important. The issue is the gross enrollment rate (GER) Indonesia to higher education is only $18.7 \%$. This figure is obtained from the ratio of the number of children studying in college divided by the number of children who should have learned in college. The number of children who must have learned in college at 25 million, and being able to access higher education with only 4.6 million. When compared to developed countries GER reached to $40 \%$ (http://nasional.kompas.com. 2011).

\section{B. The productive age of the poor group leave the formal education earlier.}

Although in the year 2007 to 2010 school enrollment keep increasing, but there are a number of students who can not afford to continue their education or dropped out of school. Dropout rate reflects school-age children who were not able to go back to school or did not complete a certain education level. This dropout rate is an indicator of success or failure of development in education. The main causes of high dropout rates is the inability of society to meet the tuition.

Up to this moment, many people have to pay the tuition, that only segments of society are able to finance their children's education in higher education. Although the Government has been setting up and providing scholarships for students from poor families, but the number was only $20 \%$ and the state university's commitment to implement the PP No.66 of 2010 has not yet been tested. The ultimate impact of this reality is the injustice in obtaining the right to education. In this case, Sindhunata (2000) states that taken as a whole, education in this country did not succeed to emancipate the people. Education should liberate people, oppress some people who can not afford instead. The following table is presented on the dropout rate by education level.

TABLE II. CALCULATION OF DROP-OUT RATE BASED ON INPUT AND OUTPUT

\begin{tabular}{|c|c|c|c|c|c|c|}
\hline \multirow[t]{2}{*}{$\begin{array}{l}\text { Level and } \\
\text { Type of } \\
\text { School }\end{array}$} & \multicolumn{2}{|c|}{ Siswa/Pupils } & \multirow[t]{2}{*}{$\begin{array}{c}\text { New Student } \\
\text { Grade I }\end{array}$} & Graduates & \multirow{2}{*}{$\begin{array}{c}\text { Drop-outs } \\
2008 / 2009 \\
2009 / 2010 \\
\text { No. }\end{array}$} & \\
\hline & $2008 / 2009$ & $2009 / 2010$ & & $2009 / 2010$ & & $\%$ \\
\hline $\begin{array}{l}\text { SD/Primary } \\
\text { School }\end{array}$ & $26,984,824$ & $27,328,601$ & $4,732,548$ & $3,943,696$ & 445,075 & 1.65 \\
\hline $\begin{array}{l}\text { SMP/Junior } \\
\text { Sec. Sch. }\end{array}$ & $8,992,619$ & $9,107,006$ & $2,997,012$ & $2,673,362$ & 209,263 & 2.33 \\
\hline $\begin{array}{l}\text { SM/Senior } \\
\text { Sec. Sch. }\end{array}$ & $6,952,949$ & $7,261,844$ & $2,594,225$ & $1,988,429$ & 296,901 & 4.27 \\
\hline SMA/GSSS & $3,857,245$ & $3,942,776$ & $1,374,807$ & $1,163,207$ & 126,069 & 3.27 \\
\hline SMK/VSSS & $3,095,704$ & $3,319,068$ & $1,219,418$ & 825,22 & 170,832 & 5.52 \\
\hline
\end{tabular}

Based on the above table, in 2008-2010 the percentage of the highest dropout rate occurs at the Senior high school, at the vocational school. According to the 20092010 Susenas percentage of the population aged 15 years or older who completed Senior high school / equivalent in 2010 was $22.83 \%$, and who managed to graduate from college was only $6.87 \%$.

\section{The quality of the Indonesian Higher education is considered low and worse}

The quality of education in Indonesia is considered poor, based on the United Nations Development Programme (UNDP), the Indonesia Human Development Index (HDI), which measures a country's human development index based on three basic dimensions are reflected in the level of education, health, and purchasing power. Among the three dimensions, the contribution of the education sector is the highest. IPM Indonesia in 2011 was 0.617 and ranked 124 of 187 countries surveyed. The rating decreased from rank 108 in 2010. The data HDI values are as follows Singapore (0.866), Brunei (0.838),
Malaysia (0.761), Thailand (0.682,) and the Philippines (0.644) (http://nasional.kompas.com. 2012).

Other issues as a part of the quality of education is the educational effectiveness. The education effectiveness relates to the quality of human resources resulted from higher education. In Indonesia, nowadays, there are a lot of low effective higher education implementation, therefore there are few higher educations in Indonesia enter the ranking of higher education in the world and even in Asia. Global Competitiveness Report 2009/2010, assessing a country's level of global competition based on the quality of higher education and Indonesia ranks $54^{\text {th }}$ of 133 countries. The number of scholars who have not worked as in February 2009 was about $13 \%$ of the total number of unemployed, or about 1.2 million people (BPS. 2009). This fact indicates that the quality of higher education in Indonesiad considered low, and this has implications for the human resources produced.

\section{Less qualified educators.}

The number of full-time lecturers with S2 and S3 education level are less than needed, consequently, the 
student competencies through the development of readymade curriculum to suit the needs of business and industry are not met. According to education statistics 2009/2010, lecturers who taught at all universities in Indonesia amounted to 233390 people, $45.60 \%$ of them were S1; $50.13 \% \mathrm{~S} 2$, and who have doctorate degrees $4.27 \%$. While the feasibility of educators at all levels of education are presented in Table III.

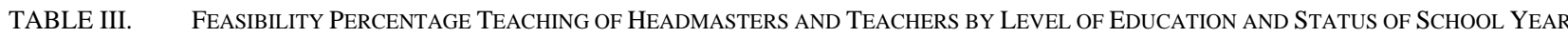
2009/2010

\begin{tabular}{|c|c|c|c|c|c|c|c|}
\hline $\begin{array}{l}\mathbf{N} \\
\mathbf{0}\end{array}$ & Education Level & State & $\%$ & Private & $\%$ & Total & $\%$ \\
\hline \multirow[t]{3}{*}{1} & $\begin{array}{l}\text { Kindergarten : } \\
\text { a. Feasible }\end{array}$ & 1.618 & 17,85 & 37.771 & 14,11 & 39.389 & 14,23 \\
\hline & Unfeasible & 7.448 & 82,15 & 229.998 & 85,89 & 237.446 & 85,77 \\
\hline & Total & 9.066 & 100,00 & 267.769 & 100,00 & 276.835 & 100,00 \\
\hline \multirow[t]{3}{*}{2} & $\begin{array}{l}\text { Primary Sch : } \\
\text { a.Feasible }\end{array}$ & 367.121 & 25,03 & 69.692 & 43,10 & 436.813 & 26,83 \\
\hline & Unfeasible & 1.099 .191 & 74,97 & 91.980 & 56,90 & 1.191 .117 & 73,17 \\
\hline & Total & 1.412 .699 & 100,00 & 161.672 & 100,00 & 1.627 .984 & 100,00 \\
\hline \multirow[t]{3}{*}{3} & $\begin{array}{l}\text { Junior High Sch: } \\
\text { a. Feasible }\end{array}$ & 341.610 & 77,18 & 144.023 & 72,24 & 485.633 & 76,24 \\
\hline & Unfeasible & 97.623 & 22,82 & 53.692 & 27,76 & 151.35 & 23,76 \\
\hline & Total & 439.233 & 100,00 & 197.715 & 100,00 & 636.948 & 100,00 \\
\hline \multirow[t]{3}{*}{4} & $\begin{array}{l}\text { Senior High Sch: } \\
\text { a.F easible }\end{array}$ & 172.032 & 85,87 & 113.728 & 72,32 & 285.760 & 87,34 \\
\hline & b.Unfeasible & 19.712 & 14,13 & 21.691 & 27,68 & 41.403 & 12,66 \\
\hline & Total & 191.744 & 100,00 & 135.419 & 100,00 & 327.163 & 100,00 \\
\hline \multirow[t]{3}{*}{5} & $\begin{array}{l}\text { Vocational High Sch: } \\
\text { a. Feasible }\end{array}$ & 83.182 & 84,45 & 136.281 & 79,28 & 219.463 & 81,16 \\
\hline & b.Unfeasible & 15.321 & 15,55 & 35.617 & 20,72 & 50.938 & 18.84 \\
\hline & Total & 98.503 & 100,00 & 171.898 & 100,00 & 270.401 & 100,00 \\
\hline \multirow[t]{3}{*}{6} & $\begin{array}{l}\text { Higher Education : } \\
\text { a.Feasible }\end{array}$ & 49.853 & 75,82 & 77.117 & 46,00 & 126.970 & 54,40 \\
\hline & b. Unfeasible & 15.898 & 24,18 & 90.522 & 54,00 & 106.420 & 45,60 \\
\hline & Total & 65.751 & 100,00 & 167.639 & 100,00 & 233.390 & 100,00 \\
\hline
\end{tabular}

Table III shows that the feasibility of teaching principals and teachers are very poor. Kindergarten principals and teachers $85.77 \%$ declared unfeasible to teach, SD 73.17\%, 23.76\% SMP; SMA 12.66\%, while $45.60 \%$ are unfeasible to teach at college. This fact contradicts to the mandate of UU RI. No. 14, 2005 on Teachers and Lecturers. An important point of this law is a teacher at all levels are recognized as professionals and the recognition must be proved by certificates of educators. Kartono (2002), chanting the importance of teacher professionalism, concerning the qualifications and competence, without ignoring the teachers' salaries.

\section{E. Maintenance of higher education facilities have not been conducted periodically}

Educational facilities at universities in Indonesia are many who do not complete, so the learning process and outcomes of graduates become less optimal. Without adequate facilities and appropriate to the needs, the education will not be optimal.

Simple facilities required for the learning process is in low level of mastery of their use and ownership as teaching aids and practice equipment, physical facilities such as buildings, learning media (in focus, labtop and Internet), library books, laboratory, and information technology. In fact there are many colleges do not have buildings, libraries, laboratories , and so on. Based on data obtained for the existing school facilities in Indonesia up
Source : Education Statistic Data Center (2011) to the high school level (high school) and vocational (vocational education) presented in Table IV.

TABLE IV. Percentage OF SCHOOl FACILITIES YeAR 2009/2010

\begin{tabular}{|c|c|c|c|c|c|c|c|c|}
\hline \multirow[b]{2}{*}{$\begin{array}{c}\text { Level } \\
\text { and } \\
\text { Type } \\
\text { of } \\
\text { School }\end{array}$} & \multirow[b]{2}{*}{$\begin{array}{l}\text { Number } \\
\text { of School }\end{array}$} & \multicolumn{7}{|c|}{ Rooms } \\
\hline & & $\frac{\sqrt[3]{3}}{3}$ & $\begin{array}{l}5 \\
5 \\
5 \\
5 \\
5 \\
5\end{array}$ & $\frac{\mathbb{N}}{\infty}$ & $\frac{5}{\frac{5}{5}}$ & 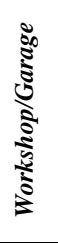 & 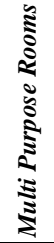 & 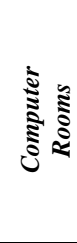 \\
\hline & & 49,42 & 59,38 & 18,92 & 1,59 & 0,55 & $\begin{array}{l}13,4 \\
9\end{array}$ & 39,14 \\
\hline $\begin{array}{l}\mathrm{SM} / \mathrm{Se} \\
\text { nior SS }\end{array}$ & 19.425 & 70,86 & 178,24 & 23,96 & 51,35 & 32,59 & $\begin{array}{l}26,0 \\
9\end{array}$ & 69,62 \\
\hline $\begin{array}{l}\text { SMA/ } \\
\text { Gen.SS }\end{array}$ & 11.036 & 65,80 & 212,28 & 19,86 & 6,61 & 2,44 & $\begin{array}{l}22,9 \\
8\end{array}$ & 53,86 \\
\hline $\begin{array}{l}\text { SMK/ } \\
\text { Voc. } \\
\text { SSS }\end{array}$ & 8.399 & 75,93 & 144,21 & 28,06 & 96,06 & 62,75 & $\begin{array}{l}29,1 \\
9\end{array}$ & 85,38 \\
\hline
\end{tabular}

In general, Table IV illustrates that school facilities have been adequate, although the government has been making improvements in the repair of damaged and unfeasible classrooms. Higher education facilities in Indonesia is not evenly distributed and a gap between the existing public universities in Java and outside Java. 
Several major universities in Java island, such as UI, UGM, ITB, UNAIR, IPB, UNDIP and UNIBRAW have been able to enter the 600 major universities of the world (Times Higher Education. 2009), and keeps striving to improve its quality as a world class university through improved facilities.

While colleges outside of Java do not only suffer a shortage of qualified teachers, but also face the problem of limited funds and lack of infrastructure. For example, the University of Palangkaraya which serves 13000 students and accept 3000 new students each year, in 2011, had a budget of around Rp 193 billion. While the 2012 budget of about USD 200 billion is not sufficient to purchase laboratory facilities.

Lack of budget for campus facilities maintenance led to a number of facilities available seems to be unmaintained. While a number of programs for 13000 students study at the University of Palangkaraya, 850 lecturers available only with the specification 25 professors, 60 doctoral, 450 graduates of the $S-2$, and the remaining S-1 well educated. In college, the faculty of science courses must have an average teaching 60 students. Whereas for science faculty to student ratio is $1: 5$, while the social science faculty with student ratio is $1: 30$.

\section{READINESS FOR HIGHER EDUCATION TOWARDS INDONESIA DEMOGRAPHIC BONUS}

In response to the challenge of the four requirements that must be met to obtain demographic bonus, Indonesia should enhance the ability of human resources in terms of competing in global markets, the use of technology that can increase revenue and productivity, and attract investors. In other words, the demographic bonus can be used as a basis for triggering an increase in productivity and economic growth through the utilization of human resources. The issue is whether the quality of the productive population in the glorious period qualify for the quality of economic growth?

Quality of human resources is the key factor to solve the problems of human resources to meet the demographic bonus. Improved quality of human resources can be achieved through education. Education can be considered as a means of investment to improve the knowledge, skills and expertise as a capital for labor can work more productively, thereby increasing their income in the future, for it increasing access to higher education is indispensable.

By considering various constraints faced by higher education, there are two things that must be implemented to improve the quantity and quality of higher education in Indonesia, by increasing the availability, affordability, and choice of higher education for every potential SMA/SMK graduates and to enhance the relevance of higher education in a strategic Indonesia's national development .

Data from the Ministry of Education and Culture shows that there are currently more than 3000 universities in Indonesia, with more than 4.3 million students and 233 thousand teachers. Number of new students are about 1.1 million students. While the number of high school graduates/equivalent is 2.2 million. Only half of high school graduate/equivalent who went to college, both Diploma and Degree levels. Private colleges can accommodate 58 percent of the total student capacity, and therefore private colleges must have the support to be able to grow more quickly .

The higher education relevance in national development strategies improved by encouraging cooperation among several state universities to foster the opening of some areas of applicable study and potentially in accordance with Kalimantan, Sulawesi, Indonesia and the region in the East. The relevance of these should be reflected in the form of grand design of higher education, supported by the cooperation between universities, colleges and the relationship between the network of scientists, workers, students, and professionals abroad to Indonesia in the brain circulation. Colleges in Java region should also be able to cooperate with universities outside of Java for the equal quality distribution.

It has been done a special intervention by the government to increase educational facilities, through construction and rehabilitation of schools and new classrooms, which will increase the gross enrollment rate (GER) high school students. government expcts in 2020 Indonesia has a workforce for at least high school education. Increased GER colleges conducted by increasing access, ensuring affordability, and availability (www.kemdiknas.go.id. 2012).

The various policies related to higher education in Indonesia to be done to improve the competitiveness of college graduates. All have been done to prepare the rise of the golden generation of students who have well "character" and "integrity" in which scientific honesty, and responsibility of being the primary capital must be owned by the children of this country. Another thing that should be owned by the golden generation is working hard without any compensation, put the interest of nation and homeland rather than selfishness, and willing to sacrifice for the progress of the nation and country Building the nation generation who have character and integrity is the challenge in education.

Characters are the values of human behavior associated with the Almighty God, self, neighbor, neighborhood, and nationality embodied in the thoughts, feelings attitudes, words, and actions based on religious norms, laws, manners, culture, and customs. Characters associated with particular traits or signs attached to an object or person. A person of character (good or bad) makes him/her looks different from others, so that a particular marker when other people recognize him/her (Dimenson. 2009). Thus, the identity of a person's character is a representation showing the obedience to the rules or moral standards applies and reflects on thoughts, feelings and inner attitude which appears in the habit of speaking, behaving and acting.

Based on the above understanding, character education can be interpreted as an effort to encourage students to grow and develop competencies to think and stick to moral principles in their lives and have the courage to do the right thing, even though faced with many challenges. Character education aims to increase the quality of implementation and educational outcomes in schools that lead to the formation of character and 
achievement of learners noble character as a whole, integrated, and balanced, according to competency standards. Through character education students are expected to be able to independently increase and use knowledge, assess and internalize and personalize the values of character and noble character will manifest in everyday behavior (http://edukasi.kompasiana.com. 2009).

G. White in Sarumpaet (2001) states that the character development is the most important effort ever given to man. While Buchori (2007) in http://edukasi.kompasiana.com (2009) says that character education should lead students to the introduction of the value of the cognitive, affective appreciation in value, and finally to the practice of real value.

Character education issues have been applied at schools need to be assessed and found out some alternative solutions and need to be developed in a more operational that it is easy to implement. Character education is to carve out a character through a process of knowing the good, loving the good, and acting the good (an educational process that involves cognitive, emotional, and physical, to the noble (Megawangi (2007) in http://edukasi.kompasiana.com. 2009).

Humans with a character believe, fear Allah and have knowledge in science and technology is called the human society. Balanced education that will allow the nation of Indonesia in a demographic bonus. A character can be formed through character education, led by charactered educators . Each faculty or teaching staff in universities have a duty embodied in the Tri Dharma college teaching, researching and devoting themselves in the community. A good combination between lectures and students who have a civil code will create a good environment for the Indonesia better progress.

Colleges assume responsibility for realizing the mandate of the National Education System Law (Education) in 2003, and PP No. 17 of 2010 on higher education. On Article 3 of the Education Law states that the national education serves to develop skills and form the character and civilization of the nation's dignity in the context of the intellectual life of the nation. Later in the article 12 paragraph 1 emphasizes that every student has the right to education based on their talents, interests and abilities. In this case, the lecturer has a very important role in realizing the character education. Lecturers should be able to use their mind and attitude to behave as models for their students. Lecturers can inplant the personality values, knowledge and skills, That it will beneficial for their students.

One of the most important components of character education is the level of competence owned by educators. Competencies to be possessed by educators as defined in the annex of the National Education Minister Regulation No. 16 of 2007, educator competency standards are developed in full of the four core competencies, the pedagogical, personality, social, and professional competencies. The four competencies are integrated in the teachers performance in order to create the process of qualified education.

(1) Pedagoic competence, the science associated with the educating of children. The pedagogic competence contains a core competence, one of which is to control the character of students from physical, moral, social, cultural, emotional, and intellectual. The teachers are expected to understand the characteristics of the learner.

(2) Personality competence, the nature and behavior typical of someone who sets it apart from others. Integration characteristic of the structures, patterns of behavior, interests, establishment, and the potential ability of a person. Good or bad personality of a teacher will greatly affect the student's personality building. Teachers are role models for students. One of the core competencies of standard personality is showing himself/herself as a stable adult personal steady, wise, and dignified.

(3) Social competence is a thing that is the core competencies of teachers in implementing standards. Therefore, the social interaction between teachers and learners should take place as well and according to prevailing norms. Core competencies in social standards is through an inclusive attitude, acting objectively, and is not discriminatory because the consideration of gender, religion, race, physical condition, family background, and socioeconomic status.

(4) The Fourth, professional competence, which is a demand for someone who is assumed his/her mandante to obtain the optimal process and outcome. Professional attitude must be developed on every educator. That he/she is a good figure imitated by learners. A professional teacher is the one who masters the material to be tought and has a discipline manner in the profession. Besides, the professional teacher is able to develop teaching material creatively and conduct reflective action.

In learning process, a professional teacher must take four steps, namely preparation, implementation, evaluation, and reflection/P3R (Suparno. 1998). John Dewey as cited by Sarkim (2005) analyzed the activities of teachers in the classroom into three acts, namely impulsive actions, routine actions, and reflective action. Impulsive actions are actions determined by the situation and this action merely done to respond to the situation. Routine action is an action taken under the authority and tradition (habits). While the reflective action is an action done by thinking some learning activities and implement they based on clear objectives on the basis of moral and ethical considerations.

Total quality management is an approach in running the civil society personality educator and has all four competencies required by the law; it must be guided and supported by good management of university leaders. Leader who has a soul and personality and character of the entrepreneurial society is indispensable. Character formed by the leadership of civil society institutions and educators will result in civil society through the application of quality culture. Application of a good culture and total quality will result in a global competitive civil society.

Some efforts to maximize the competitiveness of the organization through continuous improvement of products, services, people, processes and environment 
(Tjiptono and Anastasia. 2001). Some commitments to do by the management-lead universities by Kusuma (2006), among others: (1) emphasis on quality control standards to define strategies to achieve the set targets and consistently perform continuous improvement, (2) empower all sources there are both human resources and other funding sources, (3) increase the professionalism of the work, (4) conduct ongoing evaluation both formative evaluation and summative evaluation, (5) conduct research and study in the development program, (6) follows the changing dynamics of its time and always make innovations in all fields.

Then, the commitments above are also the basis for determining the step in the management of education. These steps include: (1) analyze the function and role of educational institutions, (2) provides the vision and mission, (3) search for the emerging gap between what has been produced with the needs and expectations of the community, (4) evaluate the public response to service education provided, (5) examine and analyze the development of science and technology, (6) addressing the problems facing the community to find solutions through academic activities, (7) analyze the future needs of HR competencies, (8) set of strategies and preventive activities in issues facing the future, (9) analyze and empowering stakeholders in the planning, processes, outcomes and feedback, (10). determine the strategic objectives achievement (Kusuma. 2006).

One of the quality management system standards of the most popular today is the ISO 9001 standard. The ISO 9001 series standards are now widely accepted as the minimum standard of quality organization system. The use of ISO 9001 standards in the countries of the world from time to time growing more rapidly. This is evidenced by the phenomenon there are more and more companies and universities in Indonesia to adopt the philosophy of ISO 9001 and ISO 9001 certification from year to year at the increasing number (Table V).

TABLE V. TOTAL OF COLLEGES RECEIVING ISO 9001 CERTIFICATES

\begin{tabular}{lllll}
\hline No. & Year & Total & $\begin{array}{c}\text { Improve } \\
\text { ment }\end{array}$ & $\begin{array}{c}\text { Improvement } \\
\text { Percentage }\end{array}$ \\
\hline 1 & 2000 & 2 & - & - \\
\hline 2 & 2001 & 2 & - & - \\
\hline 3 & 2002 & 3 & 1 & $50 \%$ \\
\hline 4 & 2003 & 4 & 1 & $33 \%$ \\
\hline 5 & 2004 & 4 & - & - \\
\hline 6 & 2005 & 21 & 17 & $425 \%$ \\
\hline 7 & 2006 & 38 & 17 & $81 \%$ \\
\hline \multicolumn{5}{c}{ Source : Profile \& Directory of Indonesian Companies ISO Certificate (LIPBI) }
\end{tabular}

In addition to the educators and commitment of leadership, curriculum content taught should reflect the character. Schwartz (2000) in Asyanti (2012) states that the university both religious and secular backgrounds can use the curriculum, especially the good effects of thought but also to build character. The curriculum is not only form the intellectual habits but also the moral habits of students.

In the grand design to deal with a demographic study of human society formation starts from early childhood education. Grand design is a reference to the conceptual and operational development, implementation, and evaluation on each pathway and levels of education. The reference configuration of the characters in the context of the totality of the psychological and socio-cultural are grouped into: 1) Olah Hati (Spiritual and emotional development); 2) Olah Pikir (intellectual development); 3) Olah Raga and Kinesthetic (Physical and kinestetic development); 4) Olah rasa dan karsa (Affective and Creativity development). At a basic level of education development of the characters can use the curriculum in character or "Character-Based Holistic Curriculum" (Character-based Integrated Curriculum). This curriculum is an integrated curriculum that touches all aspects of children's needs. A curriculum-related, not fragmented and may reflect the dimensions, skills, featuring interesting themes and contextual (http://edukasi.kompasiana.com. 2009)

The goal-based model of holistic education is shaping human character as a whole (holistic) character, which is developing the physical, emotional, social, creative, spiritual and intellectual students optimally. Megawangi (2007), in http://edukasi.kompasiana.com (2009) added that to form lifelong human Learners (true learning); it can be done in several steps as follows:

1) Applying a learning method involves the active participation of students, a method that enables to increase student motivation for all human dimensions involved actively with the subject matter is given a concrete, meaningful, and relevant in the context of his life (student active learning, contextual learning, inquiry-based learning, integrated learning).

2) Creating a conducive learning environment (conducive learning community) so that children can learn effectively in an atmosphere that gives a sense of security, reward, without threat, and giving spirit.

3) Provide character education is explicit, systematic, and continuous with the involvement aspect of knowing the good, loving the good, and the good acting.

4) The method of teaching that considers the uniqueness of each child, which is also implementing a curriculum that involves nine aspects of human intelligence.

Character education in higher education is a continuation of the character education in schooling. Therefore, every college student has a pattern of formation of different characters, according to the vision, mission, the characteristics of each college. Character education in higher education needs to design as a whole. That is, when the student enters a new territory as a new student, the faculty, the program of study, the activities of campus organizations, to graduate and become alumni.

Colleges have the option to teach character formation is to integrate character education charges with a standard curriculum. This is in line with one of the pillars of education proposed by UNESCO, namely learning to be (learning to understand myself). In Indonesia, the pillars were developed in the course of personality development, in which there is Pancasila and Citizenship course as a core curriculum required by the Director General of Higher Education circular No 914/E/T/2011, about the implementation of Pancasila course in Higher Education. 
The need on society education determined by the human character that will be generated, educators, leadership and management of educational institutions and also the facilities they have. education in Indonesia at this time should be directed at improving the quality of skills, intellectual, professional, attitude, personality and moral. Thus the people of Indonesia will be a society of dignity in the eyes of the world.

\section{REFERENCES}

[1] . Undang-Undang Nomor 19 Tahun 2005 tentang Standar Nasional Pendidikan

[2] _ . Undang-Undang Republik Indonesia No. 14 Tahun 2005 Tentang Guru dan Dosen

[3] Asyanti S. 2012. Pendidikan Karakter di Perguruan Tinggi : Sudah Terlambatkah? Prosiding Seminar Nasional Psikologi Islami. hal. 284-291

[4] BPS . 2009. Badan Pusat Statistik. Jakarta

[5] International Labor Organization. Learning and training for work in the knowledge society.

[6] Kusuma Imma Helianti. 2006. Manajemen Pendidikan di Era Reformasi. Jurnal Pendidikan Penabur - No.06/Th.V/Juni 2006

[7] Kwartolo Yuli. 2007. Brilliant Class dalam Perspektif Vygotsky. Jurnal Pendidikan Penabur - No.08/Th.VI/Juni 2007

[8] Nurkholis, 2003, Manajemen Berbasis Sekolah, Teori, Model dan Aplikasi, Jakarta: PT. Gramedia Widiasarana Indonesia.

[9] S.T. Kartono (2002). Menebus pendidikan yang tergadai. Jogjakarta: Galang Press

[10] Sarkim, T. (2005). Pendidikan calon guru menghadapi tantangan pembaharuan metode pembelajaran. Dalam Paul Suparno dan V. Triprihatmini (Eds.). Pendidikan manusia Indonesia yang etis dan terbuka. Yogyakarta: Universitas SanataDharma

[11] Schwartz, AJ. (2000). It's Not to Late to Teach College Student about Values. The Chronicle of Higher Education. Vol 46. No 40.pg A68

[12] Sindhunata. (2000). "Pendidikan hanya menghasilkan air mata". Artikel Majalah Basis, Nomor 07 - 08, Tahun Ke-49, JuliAgustus 2000, halaman 3

[13] Suparno, Paul. (1998). "Dasar dan orientasi pendidikan Yesuit”. Dalam P.J. Suwarno. Sanata Dharma menemukan jalannya.Yogyakarta: Universitas Sanata Dharma

[14] Srihadi E. 2012. Bonus Demografi: Jendela Kesempatan atau Jendela Bencana?. The Indonesian Institute Update Indonesia: Tinjauan Bulanan Ekonomi, Hukum, Keamanan, Politik, dan Sosial. Volume VII, No. 01 - Juni 2012

[15] Susenas 2006, Statistik Pemuda Indonesia 2006 , BPS, Jakarta 2006.

[16] Sutaminingsih, Raras. (2007). Aktualisasi filsafat ilmu dalam perkembangan psikologi.Fakultas Kedokteran Jurusan Psikologi Universitas Negeri Sumatera Utara

[17] Tjiptono dan Anastasia. 2001. Total Quality Management http://tempointeraktif.com/hg/kolom/.../kol,20110201-315,id.html

[18] Wijaya Muksin.2007. Pemanfaatan Teknologi Informasi dan Komunikasi. Jurnal Pendidikan Penabur - No.08/Th.VI/Juni 2007

[19] http://nasional.kompas.com/read/2011/02/23/12424241.accessed July 2012

[20] http://nasional.kompas.com/read/2012/04/17/12214022/Indeks.Pe mbangunan.Manusia.Indonesia.Sangat.Rendah.accessed July 2012

[21] http://econimist.com. 2003 Indonesia Policy Brief. 2010. http://siteresources.worldbank.org/INTINDONESIA/Resources/P ublication. . accessed July 2012

[22] http://edukasi.kompas.com/read/2009/11/16/12133939/kualitas.pe ndidikan.tinggi.indonesia tertinggal.jauh.accessed July 2012

[23] http://kampus.okezone.com.2010/12/08/373/401389/djokosantoso-indonesia-minim dosen-s2-dan-s3. accessed July 2012

[24] http://planipolis.iiep.unesco.org/upload/Indonesia/Indonesia_Educ ation_Strategic_plan_2010-2014.pdf. accessed July 2012
[25] http://rangkuman statistik pendidikan Indonesia.pdf. accessed July 2012

[26] http://www.ilo.org/public. accessed July 2012

[27] http://www.kemdiknas.go.id/kemdikbud/berita/297. accessed July 2012

[28] http://www.psp.kemdiknas.go.id/uploads/Statistik\%20Pendidikan/ 0910/index_rsp_0910.pdf. accessed July 2012 